\title{
A Study of Post Obturation Pain Following Single Visit Root Canal Treatment
}

Salma Jabeen ${ }^{1 *}$

Khurshiduzzaman ${ }^{2}$

'Medical Officer

Department of Dental and Fascio-Maxillary Surgery National Institute of Cancer Research and Hospital Mohakhali, Dhaka, Bangladesh.

${ }^{2}$ Professor and Head, Department of Dentistry Dinajpur Medical College, Dinajpur, Bangladesh.

${ }^{*}$ Correspondence to:

\section{Dr. Salma Jabeen}

Medical Officer

Department of Dental and Fascio-Maxillary Surgery National Institute of Cancer Research and Hospital Mohakhali, Dhaka, Bangladesh.

E-mail:drsi17@gmail.com

\begin{abstract}
Introduction: Root canal treatment (RCT) is a common procedure in dentistry. In recent year, single visit RCT has gained increased acceptance as a treatment procedure of RCT. One of the problem of RCT is post obturation pain. Objectives: This study was conducted to determine the incidence of post obturation pain related to single visit RCT in asymptomatic non-vital single rooted teeth. Methods: A total 60 cases of endodontically involved asymptomatic non-vital single rooted teeth without any evidence of periapical radiolucency in radiograph, were selected for this study. The canals of all teeth were prepared and filled using the standarized preparation and lateral condensation filling technique. The frequency of post obturation pain was recorded as no pain, slight, moderate and severe pain and evaluated at the day 1 and at the day 7 after obturation. Result: Out of the 60 patients involved in the study, 37 patients had no pain, 12 patients had slight pain and 11 patients had moderate pain at the day 1 after post obturation. At the day 7 after post obturation, 50 patients had no pain, 8 patients had slight pain and 2 patients had moderate pain. No one showed severe pain in both follow up days. Conclusion: Statistically significant differences were found in the incidence and degree of pain between two follow up days. Incidence of pain was more in $1^{\text {st }}$ post obturation day and decreased thereafter.
\end{abstract}

Key words: RCT; Single visit; Post obturation pain.

\section{INTRODUCTION}

Root canal treatment (RCT) or endodontic treatment is a common procedure in dentistry. Successful RCT is characterized by an absence of symptoms and clinical signs in teeth without radiographic evidence of periodontal involvement. The success of RCT depends on a series of variables related to the preoperative condition of the tooth, as well as the endodontic procedure ${ }^{1}$. The procedure can be done in single visit or multivisit ${ }^{2}$. Endodontic treatment can be followed by numerous short and long term complications ${ }^{3}$. Some of the problem of RCT is post obturation pain, inter appointment pain and swelling ${ }^{4}$. Post obturation pain is the pain of any degree after endodontic treatment ${ }^{5}$. Development of pain after completion of RCT may undermine patient's confidence in the clinician and acceptance of the procedure ${ }^{6}$.

The etiological factors for post obturation pain or flare ups are complex and involved various aspects such as-type of treatment (initial treatment or re-treatment), number of appointment (single or multiple visit), mechanical or chemical injury during clinical procedure, microbial factors related to the contents of infected root canal etc $^{7}$. Among these, one of the factors "numbers of appointments" (single or multi visit) may predispose the development of post obturation pain and flare-up.

Multi visit root canal treatment has long been taught to undergraduate dental students and is practiced as a safer procedure ${ }^{8,9}$. But patients request and expectation of treatment have made single visit RCT popular among dental surgeons, as it is less time consuming and more economical ${ }^{10}$, and as a consequence, more appropriated to the needs of iterant and busy patients ${ }^{11}$. Single visit RCT has been recommended in case of pulpal inflammation, traumatic pulpal exposure or necrotic pulp with a sinus tract $^{8}$. 
However, current studies demonstrated that the incidence of post obturation pain was not increased in patients who were treated in single visit versus those treated in multiple visits endodontics ${ }^{7,12,13,14}$. Studies on post obturation pain in asymptomatic non-vital tooth were limited. A nalysis of post obturation pain may lead to modification of treatment and technique. Therefore, this study was aimed to determine the post obturation pain related to the single visit RCT in asymptomatic non-vital single rooted teeth.

\section{MATERIALS AND METHODS}

A total of 60 cases of endodontically involved asymptomatic non-vital single rooted teeth without any evidence of periapical radiolucency in periapical radiograph were selected for this study who attended at the Department of Conservative Dentistry and Endodontics, Dhaka Dental College \& Hospital, Bangladesh. It was a prospective study and was carried out during the period from January 2009 to December 2009. Diagnosis of non vital asymptomatic, necrotic tooth was confirmed by pulp sensitivity test applying heat and cold method and examination of preoperative periapical radiograph was done for excluding periapical lesion cases.

The canals of all teeth were prepared and filled using the standardized preparation and lateral condensation filling technique. At the first appointment, the teeth was isolated, biomechanically prepared, dried and obturated with Gutta percha points and zinc oxide eugenol sealer using lateral condensation technique. The patient was asked to report, record or interviewed any pain experience at the day 1 and 7 after obturation. The presence or absence of pain, or the appropriate degree of pain was recorded and graded as-

1. No pain (Grade- 0 ) - the treated tooth feels normal.

2. Slight pain (Grade-I) - any discomfort, no matter how many brief in duration that do not require medication.

3. M oderate pain (Grade-II)- pain tolerable or is tolerable by analgesics.

4. Severe pain (Grade-III)-pain not responding to analgesics, disturb normal activity or sleep or impairment of masticatory function.

The data was analyzed by a computer based software program, SPSS version-12. Pvalue $<0.05$ Considered as significant.

\section{RESULTS}

Total number of cases was 60 . Out of these, male was $32(53.3 \%)$ and female was $28(46.7 \%)$. The age of the patients was ranges from $15-40$ years (mean age $22.9 \pm 6.68$ years). In clinical evaluation, $31(51.7 \%)$ patients had history of trauma, $31(51.7 \%)$ had discolouration of tooth and $29(48.3 \%)$ had carries of the tooth. The periodontal condition was avearage in $59(98.3 \%)$ patients. By occupation, most of the patients were students ( $n=34,56.7 \%)$ followed by house wife $(n=14,23.3 \%$ ). $39(65 \%)$ teeth were of maxillary arch and $21(35 \%)$ were mandibular arch.

Out of 60 patients, 37(61.6\%) experienced no pain, 12(20\%) slight pain and $11(18.4 \%)$ moderate pain i.e $23(38.4 \%)$ experienced pain at the day 1 after post obturation. Where as $50(83.3 \%)$ patients had no pain, $8(13.3 \%)$ had slight pain and $2(3.3 \%)$ showed moderate pain at the day 7 after post obturation.
No one experienced severe pain in both follow-up days (Table-1). Female were found to record more pain than males and older patients ( $\geq 25$ years) percieved more pain than younger patients at both day I and 7 after post obturation. When considering arch group and type of teeth, pain is experienced more in mandibular group and pre- molar teeth than maxillary and anterior teeth at both $1^{\text {st }}$ and $7^{\text {th }}$ post obturation days (Table $2 \& 3$ ).

Table 1 : Degree/ severity of pain following $1^{\text {st }}$ and $7^{\text {th }}$ post obturation day.

\begin{tabular}{|c|c|c|c|c|c|}
\hline Follow up & $\begin{array}{l}\text { Pain } \\
\text { No pain }\end{array}$ & $\begin{array}{c}\text { Total } \\
\text { Slight pain }\end{array}$ & Moderate pain & Severe pain & \\
\hline $\begin{array}{l}1^{\text {st }} \text { post } \\
\text { obturation day }\end{array}$ & $37(61.6 \%)$ & $12(20 \%)$ & $11(18.3 \%)$ & $00(00 \%)$ & $60(100 \%)$ \\
\hline $\begin{array}{l}7^{\text {th }} \text { post } \\
\text { obturation day }\end{array}$ & $50(83.4 \%)$ & $08(13.3 \%)$ & $02(3.3 \%)$ & $00(00 \%)$ & $60(100 \%)$ \\
\hline
\end{tabular}

Chi-square value- 8.96, df-2, P value $<0.05(0.010)$, Significant.

Table 2: Pain following $1^{\text {st }}$ post obturation day in different variables.

\begin{tabular}{|c|c|c|c|c|}
\hline Variables & $\begin{array}{l}\text { No pain } \\
\text { experienced. } \\
\text { No. }(\%)\end{array}$ & $\begin{array}{l}\text { Pain } \\
\text { experienced. } \\
\text { No. }(\%)\end{array}$ & $\begin{array}{l}\text { Total } \\
\text { No.(\%) }\end{array}$ & P value \\
\hline $\begin{array}{l}\text { Gender- } \\
\text { Male } \\
\text { Female }\end{array}$ & $\begin{array}{l}21(35 \%) \\
16(26.7 \%)\end{array}$ & $\begin{array}{l}11(18.3 \%) \\
12(20.0 \%)\end{array}$ & $\begin{array}{l}32(53.3 \%) \\
28(46.7 \%)\end{array}$ & $0.5^{\mathrm{NS}}$ \\
\hline $\begin{array}{l}\text { Age- } \\
<25 \text { years } \\
\geq 25 \text { years }\end{array}$ & $\begin{array}{l}24(40 \%) \\
13(21.7 \%)\end{array}$ & $\begin{array}{l}10(16.6 \%) \\
13(21.7 \%)\end{array}$ & $\begin{array}{l}34(56.6 \%) \\
26(43.4 \%)\end{array}$ & $0.104^{\mathrm{NS}}$ \\
\hline $\begin{array}{l}\text { Arch- } \\
\text { Mandible } \\
\text { Maxilla }\end{array}$ & $\begin{array}{l}07(11.7 \%) \\
30(49.9 \%)\end{array}$ & $\begin{array}{l}14(23.3 \%) \\
09(15.0 \%)\end{array}$ & $\begin{array}{l}21(35 \%) \\
39(65.0 \%)\end{array}$ & $0.001^{\mathrm{S}}$ \\
\hline $\begin{array}{l}\text { Type of teeth- } \\
\text { Anterior } \\
\text { Pre-molar }\end{array}$ & $\begin{array}{l}29(48.33 \%) \\
08(13.33 \%)\end{array}$ & $\begin{array}{l}10(16.6 \%) \\
13(21.6 \%)\end{array}$ & $\begin{array}{l}39(65.0 \%) \\
21(35.0 \%)\end{array}$ & $0.005^{\mathrm{S}}$ \\
\hline
\end{tabular}

* NS $=$ N ot significant, S-Significant

Table 3 : Pain following $7^{\text {th }}$ post obturation day in different variables

\begin{tabular}{|c|c|c|c|c|}
\hline Variables & $\begin{array}{l}\text { No pain } \\
\text { experienced } \\
\text { No. }(\%)\end{array}$ & $\begin{array}{l}\text { Pain } \\
\text { experienced } \\
\text { No. }(\%)\end{array}$ & $\begin{array}{l}\text { Total } \\
\text { No. }(\%)\end{array}$ & P value \\
\hline $\begin{array}{l}\text { Gender- } \\
\text { Male } \\
\text { Female }\end{array}$ & $\begin{array}{l}28(46.7 \%) \\
22(36.7 \%)\end{array}$ & $\begin{array}{l}04(6.7 \%) \\
06(10.0 \%)\end{array}$ & $\begin{array}{l}32(53.3 \%) \\
28(46.7 \%)\end{array}$ & $0.35^{\mathrm{NS}}$ \\
\hline $\begin{array}{l}\text { Age } \\
<25 \text { years } \\
\geq 25 \text { years }\end{array}$ & $\begin{array}{l}31(51.7 \%) \\
19(31.6 \%)\end{array}$ & $\begin{array}{l}03(5.0 \%) \\
07(11.7 \%)\end{array}$ & $\begin{array}{l}34(56.7 \%) \\
26(43.3 \%)\end{array}$ & $0.62^{\mathrm{NS}}$ \\
\hline $\begin{array}{l}\text { Arch- } \\
\text { Mandible } \\
\text { Maxilla }\end{array}$ & $\begin{array}{l}15(25.0 \%) \\
35(58.3 \%)\end{array}$ & $\begin{array}{l}06(10.0 \%) \\
04(6.7 \%)\end{array}$ & $\begin{array}{l}21(35.0 \%) \\
39(65.0 \%)\end{array}$ & $0.04^{\mathrm{S}}$ \\
\hline $\begin{array}{l}\text { Type of teeth- } \\
\text { Anterior } \\
\text { Pre-molar }\end{array}$ & $\begin{array}{l}35(58.3 \%) \\
15(25.0 \%\end{array}$ & $\begin{array}{l}04(6.7 \%) \\
06(10.0 \%)\end{array}$ & $\begin{array}{l}39(65.0 \%) \\
21(35.0 \%)\end{array}$ & $0.06^{\mathrm{NS}}$ \\
\hline
\end{tabular}

$* N S=N$ ot significant, S-Significant 


\section{DISCUSSION}

The present study was performed to evaluate the incidence of post obturation pain in single visit root canal therapy in asymptomatic non-vital single rooted teeth. This study showed no pain in $83.4 \%$ patients at $7^{\text {th }}$ post obturation days, which is similiar to 0 gini $\& U$ doye ${ }^{4}$ and $K$ ane et $a 1^{15}$ where it was $83.7 \%$ and $81.25 \%$ respectively. But in $1^{\text {st }}$ post obturation day, Ogini \& Udoye 4 found no pain in $45.8 \%$, Albashaireh \& A Inegrish ${ }^{16}$ found $72.54 \%$, El-M ubarak et $\mathrm{al}^{2}$ found $90.6 \%$ of patients. Where as in this study, it was $61.6 \%$. It may be due to that they observed pain in both vital and non-vital as well as all types of teeth where as this study was caried out in only non vital single rooted teeth.

This study showed, post obturation pain in $16.6 \%$ patients where as it was $18.3 \%$ and $3.7 \%$ reported by Oginni \& U doye ${ }^{4}$ and Al-Negrish \& Habahbeh ${ }^{17}$ respectively.

The incidence of post obturation pain was more during the $1^{\text {st }}$ day after obturation. However, at $7^{\text {th }}$ day, post obturation pain decreased significantly which was found in agreement with the findings of other studies ${ }^{18,19,20,21}$.
In $1^{\text {st }}$ post obturation day as well as $7^{\text {th }}$ post obturation day females reported more pain than males. These results support findings of previous workers ${ }^{16,17,22,23,24,25,26}$. Female patients experienced more pain than male patients, a possible explanation is that biological differences between genders may explain increased pain prevalence in females ${ }^{17}$.

This study showed more pain was perceived by older patients than younger, which is supported by findings of Torabinejad et $\mathrm{al}^{27}, \mathrm{O}^{\prime} \mathrm{K}$ eefe ${ }^{28}$ and Cheng et $\mathrm{al}^{29}$. Regarding the arch of teeth, mandibular arch showed more pain than maxillary arch which is similiar to El-M ubarak et al ${ }^{2}$, Segura-Egea et al ${ }^{22}$, Watkins et $\mathrm{al}^{30}$ and Alcam $\&$ Tinaz ${ }^{31}$.

In this study, more pain observed in pre molar teeth than anterior group of teeth. This is supported by Segura-Egea et $\mathrm{al}^{22}$ and $\mathrm{K}$ alhoro $\& M \mathrm{irza}^{32}$. However, it disagree with Imura \& Zuolo ${ }^{7}$, who showed more pain in anterior teeth.

In conclusion, post obturation pain is one of the major factors when evaluating endodontic treatment. Incidence of pain more in $1^{\text {st }}$ post obturation day and decreased thereby.

\section{REFERENCES}

1. Figini L, Lodi G, Gorni F, Gagliani M. Single versus M ultiple visits for endodontic treatment of permanent teeth : A Cochrane Systemic Review. Journal of Endodontics, 2008; 34(9): 1041-47.

2. EL M ubarak A.H.H, A bu-bakr NH, I brahim Y E. Postoperative pain in M ultiple visit and single visit root canal treatment. Journal of Endodontics, 2010; 36: 36-39.

3. Glennon J.P, N gY -L, Setchell D.J, Gulabi vala K. Prevalence of and factors affecting post preparation pain in patients undergoing two visit root canal treatment. International Endodontic J ournal, 2004; 37: 29-37.

4. Oginni A.O, U doye C.I . Endodontic Flare-ups : Comparison of incidence between single and multiple visit procedures in patients attending a Nigerian teaching hospital. BM C Oral Health, 2004;4(1): 4.

5. Walton R, Fouad A. Endodontic inter appointment flare-ups : a prospective study of incidence and related factors. Journal of Endodontics, 1992;18(4): 172-7.

6. Ng Y-L, Glennon J.P, Setchell D.J, Gulabivala K . Prevalence of and factors affecting post obturation pain in patients undergoing root canal treatment. International Endodontic J ournal, 2004; 37: 381-391.

7. Imura N, Zuolo M .I. Factors associated with endodontic flare-ups : a prospective study . International Endodontic J ournal. 1995 ; 28 : 261-5.

8. Grossman L. I, Oliet S, Del RioCE. Endodontic Practice. $11^{\text {th }}$ edition ; L ea and Febiger, Philadel phia PA ; 1998.

9. Calhoun R. L, Landers R. R. One appointment Endodontics therapy : a nationwide survey of endodontists . Journal of Endodontics, $1982 ; 8: 35-40$.

10. Pekruhn R.B. Single visit endodontics therapy ; a preliminary Clinical study. Journal of the A merican Dental A ssociation, 1981 ; 103(6) : 875-7.

11. Jureak J.J, B ellizzi R, Loushine R.J. Successful Single visit endodontics during operation Desert shield. Journal of Endodontics, 1993;198:412-13.

12. William S. A lbasaireh ZSM, A Inegrish AS. Postobturation pain after single- visit and multiple -visit endodontic therapy. J ournal of Dentistry, 1998;26:227-32.

13. Harqreaves KM . single visit more effective than multiple visit root canal treatment? Evidence based D entistry, 2006; 7:13-14.

14. Eleazer P.D, Eleazer K.R. Flare-up rate in pulpally necrotic molars in one visit versus two visit endodontic treatment. J ournal of Endodontics, 1998;24:614-6.

15. K ane AW, Sarr M, Faye B, Toure B, Ba A . Incidence of post operative pain in single session root canal therapy. Dakar M edicine, 1999;44(1):114-8.

16. A lbashaireh Z.S.M , A Inegrish A.S. Post obturation pain after single and multiple -visit endodontic therapy. A prospective study. Journal of Dentistry, 1998;26:227-32.

17. AL-N egrish A.R, Habahbeh R. Flare up rate related to root canal treatment of asymptomatic pul pally necrotic central incisor teeth in patients attending a military hospital. J ournal of Dentistry, 2006;34(9):635-40. 


\section{REFERENCES}

18. Fox J, A tkinson J.S, Dinin A .P, G reenfield E, Hechtman E, Reeman CA, et al. Incidence of pain following one visit Endodontic treatment. Oral surgery Oral M edicine and Oral Pathology, 1970;30:123-30.

19. M ulhern JM, Patterson SS, N ewton CW, Ringel A M . Incidence of post operative pain after one appointment Endodontic treatment of asymptomatic pulpal necrosis in single rooted teeth. Journal of Endodontics, 1982;8:370-5.

20. A Icam T. Incidence of post operative pain following the use of different sealers in immediate root canal filling. Journal of Endodontics, 1985;11:135-7.

21. Koba K, K imuraY, M atsumoto K, et al. Post operative symptoms and healing after Endodontic treatment of infected teeth using pulsed Nd:YAG Laser. Endodontics and Dental Traumatology, 1999;15:68-72.

22. Segura -Egea J.J, Cisne ros-Cabello R, Liamas-Carreras J.M, Velasco-Ortega E. Pain associated with root canal treatment. International Endodontic J ournal, 2009;42:614-20.

23. Jariwala S.P, Goel B.R. Pain in Endodontics. Causes, prevention and management. Endodontology, 2001;13:63-66.

24. Unru AM, Ritchie J, M erskey H. Does gender affect appraisal of pain and pain coping strategies? Clinical journal of pain, $1999 ; 15: 31-40$

25. Clem W.H. Post treatment endodontic pain. J ournal of the A merican Dental A ssociation, 1970;81:1166-70.

26. Maddox D.L. Walton R.E, Davis C.O. Incidence of post treatment endodontic pain related to medicaments and other factors. J ournal of Endodontics, 1977;3:447-52.

27. Torabinejad M , K ettering J.D, M c Graw J.C, Cummings R.R, D wyer T.G, Tobias T.S. Factors A ssociated with Endodontics inter appointment emergencies of teeth with necrotic pulps. Journal of Endodontics, 1988;14:261-6.

28. O'K eefe E.M. Pain in Endodontic therapy: Preliminary study. J ournal of Endodontics , 1976;2(10):315-9.

29. Cheng Y, Cheung G.S.P, Bian Z, Peng B. Incidence and factors associated with endodontic inter appointment emergency in a dental teaching hospital in China. J ournal of Dentistry, 2006; 34:516-21.

30. Watkins C.A, Logan H.L, K irchner H.L, A nticipated and experienced pain associated with endodontic therapy. Journal of the A merican Dental A ssociation, 2002;133:45-54

31. Alcam T, Tinaz A .C, Interappointment emergencies in teeth with necrotic pulps. J ournal of Endodontics, 2002;28(5):375-77.

32. Kalhoro F.A, M irza A.J. A study of Flare ups following single visit root canal treatment in Endodontic patients. Journal of the College of Physicians and Surgeons Pakistan, 2009;19(7):410-412. 